\title{
Basin and petroleum system analysis in the southeastern Persian Gulf basin: a 2D basin modeling approach
}

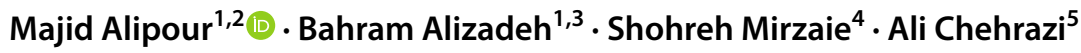

Received: 9 July 2021 / Accepted: 19 September 2021 / Published online: 24 September 2021

(c) The Author(s) 2021

\begin{abstract}
A regional 2D conceptual model was constructed to study the hydrocarbon systems associated with the Middle Sarvak source rock (Cenomanian) in the southeastern Persian Gulf basin. The 2D cross section used for this purpose was $135 \mathrm{~km}$ long and encompassed a total of 17 depositional units with the Late Jurassic Surmeh Formation at the base and the Aghajari/Mishan sequences at the top. Compositional type II-S kinetics was considered for the Middle Sarvak source rock, and the model predictions were calibrated against observe data (corrected bottom hole temperatures and vitrinite reflectance data) coming from 4 wells located on the studied cross section. Our results indicate that hydrocarbons predominantly migrate laterally from east to the west of the study area, thereby sequentially charging potential traps en-route. The interaction between facies patterns and geodynamic evolution controls both the distribution and quality of hydrocarbon accumulations in the study area. The calibrated 2D model reliably predicts most of the present-day hydrocarbon occurrences in the study area and explains the present-day variations in their bulk properties. Our findings provide new insights about the unconventional plays associate with the Middle Sarvak source rock especially in the central parts of the southeastern Persian Gulf basin.
\end{abstract}

Keywords Southeastern Persian Gulf basin $\cdot$ 2D basin and petroleum system modeling - Cenomanian source rock · Middle Sarvak formation · Unconventional oil resources

\section{Introduction}

The Persian Gulf basin is renowned for huge volumes of gas accumulations in the Paleozoic series and considerable amounts of oil reserves within the Jurassic through Cretaceous sediments (Ghazban 2007). Geochemical studies on oils and source rock samples from this basin have testified the presence of several important petroleum systems in the

Majid Alipour

alipour@scu.ac.ir

1 Department of Petroleum Geology and Sedimentary Basins, Faculty of Earth Sciences, Shahid Chamran University of Ahvaz, Ahvaz, Iran

2 Drilling Research Center (DRC), Shahid Chamran University of Ahvaz, Ahvaz, Iran

3 Petroleum Geology and Geochemistry Research Center (PGGRC), Shahid Chamran University of Ahvaz, Ahvaz, Iran

4 Pars Petro Zagros Engineering and Services Co. (PPZ), Tehran, Iran

5 Iranian Offshore Oil Company (IOOC), Tehran, Iran area (Alizadeh et al. 2017; Hosseiny et al. 2017; Rabbani et al. 2014).

Recent seismic studies in the Iranian sectors of the prolific Persian Gulf region (OEOC, 2014) has resulted in numerous oil and gas discoveries within the Cretaceous Series. The Middle Sarvak Formation (Cenomanian) is believed to be an important source rock within the Cretaceous petroleum system of the eastern Persian Gulf basin (Alipour, 2017; Hosseiny et al. 2016). This source rock is suggested to charge the overlying Mishrif and Ilam carbonates in some oilfields of the study area (Alipour et al. 2017; Alizadeh et al. 2017; Hosseiny et al. 2017). Stratigraphic equivalents of the Middle Sarvak source rock have been geologically and geochemically assessed in the United Arab Emirates (the Shilaif Formation) (Al-Zaabi et al. 2010; Azzam and Taher, 1993; Loutfi and El Bishlawy, 1986) and in the Iraq (the upper parts of the Qmachuqa Formation) (Ameen and Gharib, 2014). The existing organic geochemical data and basin modeling results from the United Arab Emirates collectively suggest that hydrocarbons accumulated within the Mishrif reservoir are sourced from the Cenomanian Shilaif source rock. 
Notwithstanding the large volume of geochemical research, the dynamic evolution of the Cretaceous petroleum system has rarely been documented in the eastern Persian Gulf basin and neighboring countries. Previously, modeling techniques were applied to highlight the geohistory evolution of local kitchens in the study area (Alipour, 2017; Alipour et al. 2017). These studies suggested that the timing and extent of hydrocarbon generation from the Middle Sarvak source rock were predominantly controlled by variations in the depth of burial. Previous modeling studies have also suggested that local stratigraphy can critically control the distribution of accumulated hydrocarbons (Alipour et al. 2016a). These studies suggested that biodegradation processes can influence generated hydrocarbons at structurally shallower regions.

Multi-dimensional modeling can be particularly useful to study the generation of hydrocarbons and their migration/ accumulation histories. In addition, these techniques provide new insights about remaining exploration potential of an area by identifying new stratigraphic or unconventional plays (Alipour et al. 2021; Baur et al. 2017; Hantschel and Kauerauf, 2009; İnan et al. 2017). The aim of this study was to gain a deeper insight about the evolution of the Cretaceous petroleum system in the eastern Persian Gulf basin. For this end, a regional 2D model was constructed across the depositional basin of this source rock (Fig. 1). Such cross sections are believed to provide critical information about the elements and processes of the petroleum system (Magoon and Dow, 1994; Peters et al. 2017). Our main emphasize was on analyzing the generation and migration of hydrocarbons from the Middle Sarvak source rock. In addition, we use modeling techniques to study the present-day variations in the bulk properties of accumulations and explain the heavy bitumen occurrences in some fields. Finally, the potential for unconventional oil resources within the Middle Sarvak source rock is assessed based on our modeling results.

\section{Background geology}

The Mesozoic stratigraphy of the Persian Gulf basin is characterized by episodic development of intra-shelf basins over the northeastern margin of the Arabian plate (Sharland et al. 2001; Van Buchem et al. 2011). During Aptian and Cenomanian, these basins resulted in deposition of organicrich sediments which adjoined porous rim carbonates on

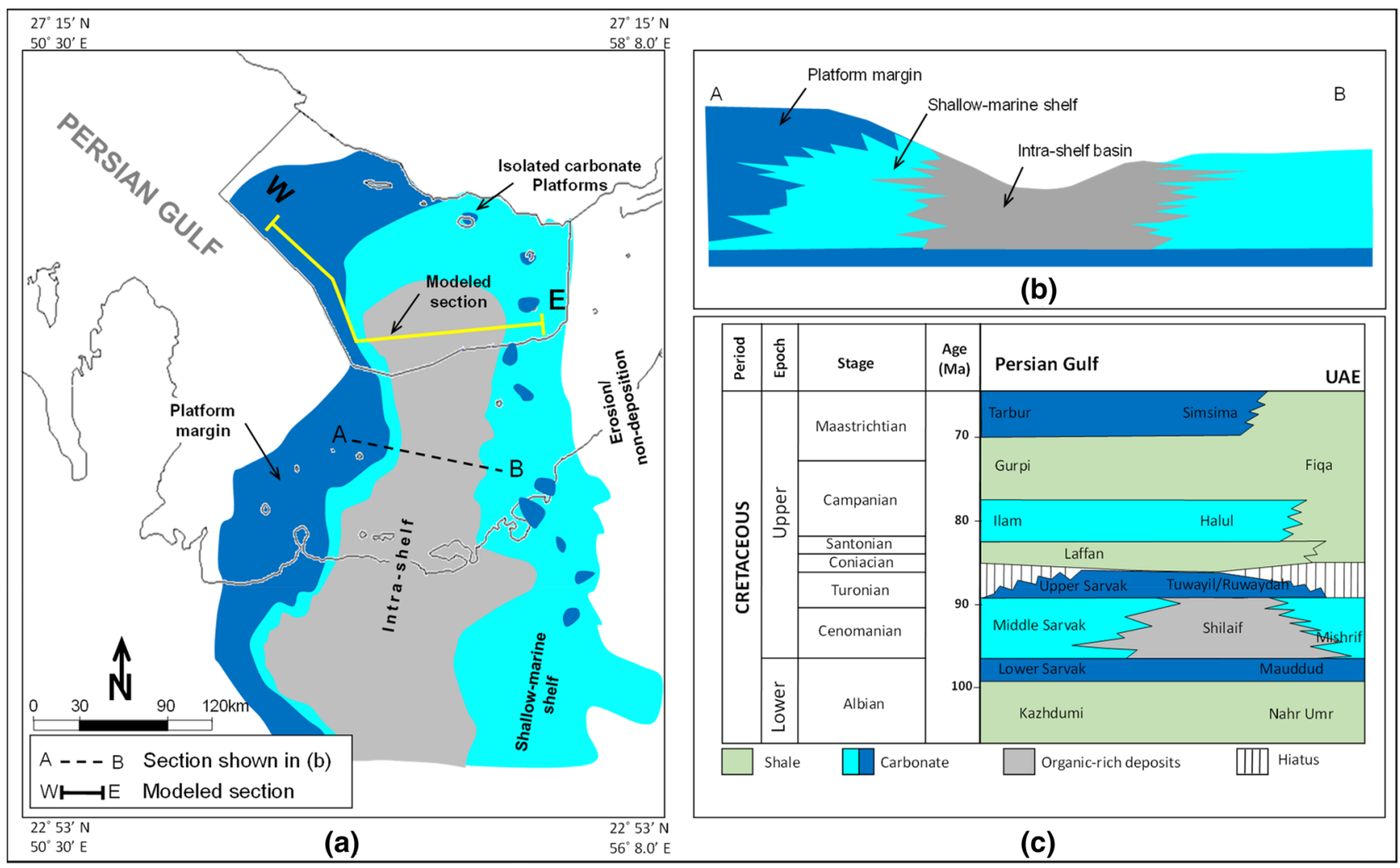

Fig. 1 General paleo-geographic setting of the Middle Sarvak source rock (Cenomanian) in the Persian Gulf Basin (a) (modified after Vahrenkamp et al. 2015). The environments of deposition are illustrated along the A-B dashed line (b). A generalized stratigraphic column of the Upper Cretaceous in the eastern Persian Gulf basin is provided in (c). Note that our 2D conceptual model is constructed along the W-E line shown in (a) 
their margins (Vahrenkamp et al. 2015). The Cenomanian intra-shelf basin was developed following the deposition of the lower parts of the Sarvak Formation, which are regionally continuous and dominated by carbonates (Razin et al. 2010). These carbonates are overlain in the west and east by shallow-marine carbonates of the Mishrif platform rimming an NE-SW trending intra-shelf basin in the central parts of the study area (Vahrenkamp et al. 2015) (Fig. 1a,b). The organic-rich facies of the Middle Sarvak Formation was deposited within this intra-shelf basin, while the riming carbonate platforms could be exposed at times of relative sealevel fall (Al-Zaabi et al. 2010; Van Buchem et al. 2002).

The infill of this basin was provided by deposition of the upper parts of the Sarvak Formation during the subsequent transgression and increase in carbonate production (Vahrenkamp et al. 2015). A major sea level fall during the Turonian resulted in subaerial exposure of the uppermost parts of the Sarvak Formation in most areas across the Persian Gulf basin (Hajikazemi et al. 2010; Motiei, 1993) (Fig. 1c). Following this regional Turonian unconformity, exceptional subsidence (due to ophiolite obduction) led to the deposition of the Laffan Formation (Lawa et al. 2013; Omar et al. 2015; Sharland et al. 2001). This formation is composed of black shales in the study area and acts as a potential seal rock for the underlying Mishrif reservoirs (Alipour, 2017; Ghajar et al. 2011). However, these shales exhibit a general trend of decreasing thickness eastwards in the Persian Gulf basin, which can cause occasional escape of hydrocarbons into the Campanian Ilam carbonates above (Al-Zaabi et al. 2010; Alipour et al. 2016a). In such cases, the thick shales of the Gurpi and Pabdeh formations can act as the ultimate seal rock for these migrating hydrocarbons (Fig. 1c).

\section{Material and methods}

\section{Input data}

For the purpose of the present study, a regional 2D cross section was extracted from a 3D geological model of the studied area. The section was oriented to encompass the Cenomanian intra-shelf basin (Figs. 1a, 2). We followed a two-step workflow for defining the thickness and geographic extension of the source rock interval in our model. In the first step, well logs (including gamma ray, sonic and resistivity), lithology data (carbonate/shale ratio), and organic geochemistry data (TOC and HI) from a total of 18 offshore wells were used to delineate the extent of the Cenomanian intra-shelf basin in the study area (Figs. 1,2). The organic-rich intervals are often characterized with high gamma ray readings (e.g., $80-110^{\circ} \mathrm{API}$ ), low sonic transit time, and high resistivity. Similarly, these zones exhibited lower carbonate/shale ratios with higher TOC and HI readings (Fig. 3a). During the second step, the same information were used to define the thickness of the organic-rich interval in our model. The organic-rich zone is generally thicker in the center of the intra-shelf basin, exceeding $40 \mathrm{~m}$ in the vicinity of Well-II (Fig. 4). However, its thickness decreases to less than $30 \mathrm{~m}$ on the eastern and western margins of the intra-shelf basin until it is eventually replaced by shallow-water, organic-lean carbonates of the Mishrif Formation (Figs. 2, 4).

The main input parameters for constructing the $2 \mathrm{D}$ conceptual model, including the geological (thickness, ages, paleo-bathymetries and lithofacies information) and geochemical (Rock-Eval pyrolysis and organic petrography) information, were also obtained from the same 18 wells (Table 1 and Fig. 2).

Geochemical characteristics of the Cenomanian source rock were obtained from Rock-Eval pyrolysis data of a total of 35 samples from different oilfields (see also Hosseiny et al. 2016) (Figs. 2, 3a). The type of organic matter was defined based on previous studies as reactive type II with relatively high sulfur content (Alipour, 2017; Alipour et al. 2016b, 2019; Hosseiny et al. 2016). Due to the lack of published information regarding hydrocarbon generation kinetics from this source rock, a compositional kinetic scheme corresponding to type II-S (Behar et al. 1997) was selected from the default library of PetroMod ${ }^{\circledR} 2012$ software (Fig. 3b).

\section{Model building}

The boundary conditions of the model were set based on our experience from previous modeling studies in the southeastern Persian Gulf basin (Alipour et al. 2017, 2016a, 2014). In brief, considering the tectonic quiescence of the study area during the Cretaceous, a constant heat flow of $50 \mathrm{~mW} /$ $\mathrm{m}^{2}$ was considered through time using McKenzie Model of the PetroMod ${ }^{\circledR} 2012$ software (Table 1). In addition, a constant thickness of eroded sediments was considered for the upper parts of the Sarvak Formation following the Turonian unconformity (Table 1).

The obduction of ophiolites during the Late Cretaceous is suggested to have caused reactivation of old basement features and initiation of halokinetic movements across the Arabian Plate (Sharland et al. 2001). However, these processes are not well constrained in the study area. Therefore, we did not consider them in the present study because their insertion into our models would incur large uncertainties upon the predictions. The temperature at the sediment-water interface (SWIT) was automatically calculated using the PetroMod ${ }^{\circledR}$ 2012 functionality based on the pre-assigned paleo-water depth (PWD) information (Wygrala, 1989).

Modeling predictions were calibrated against measured values of present-day temperature (i.e., corrected bottomhole temperature) and vitrinite reflectance data (following

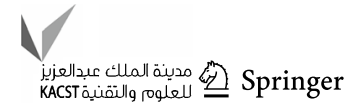


Fig. 2 Approximate geographic extension of the organic-rich Middle Sarvak source rock in the eastern Persian Gulf basin. Data for UAE basin are based on Azzam and Taher (1993).

The distribution of offshore wells used for constructing and calibrating the 2D conceptual model along the studied transect is also shown

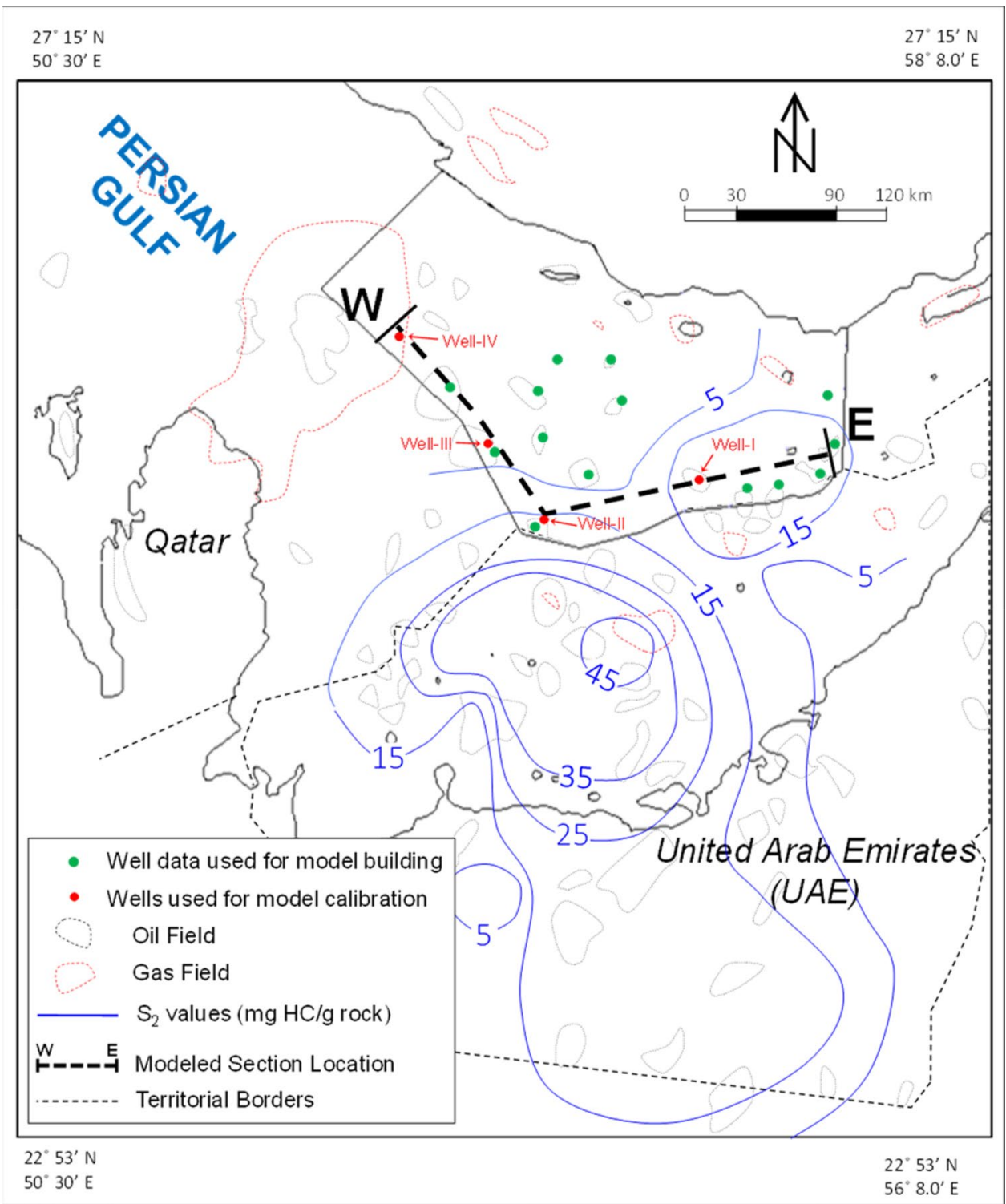

the method of Sweeney and Burnham, 1990) from four wells located on the modeled cross section (Fig. 2 and Table 2).

\section{Results}

\section{Model calibration}

After running a simulation on the constructed 2D model, the modeling results should be checked against observation data. A satisfactory calibration means that a reasonable agreement exists between modeling predictions, on the one hand, and the natural conditions, on the other (e.g., measured temperature and vitrinite reflectance data from existing wells). Calibration profiles (Fig. 5) indicate a satisfactory match between model predictions and the observe data, meaning that thermal evolution of the studied source rock can be reliably evaluated using our modeling approach.

\section{Timing and extent of hydrocarbon generation}

Thermal maturity profiles for the studied 2D section indicate relatively higher maturity and elevated transformation ratio in the eastern parts (Fig. 6). Generally, the onset of hydrocarbon generation from the Middle Sarvak source rock corresponds to the deposition of the Gurpi and Pabdeh formations (i.e., from c.a. $60 \mathrm{Ma}$ ). These formations have a relatively higher thickness in the eastern parts of the studied section (Figs. 4, 7), and therefore, the earliest phases of hydrocarbon generation would correspond to these deeply buried areas (Fig. 7a). 

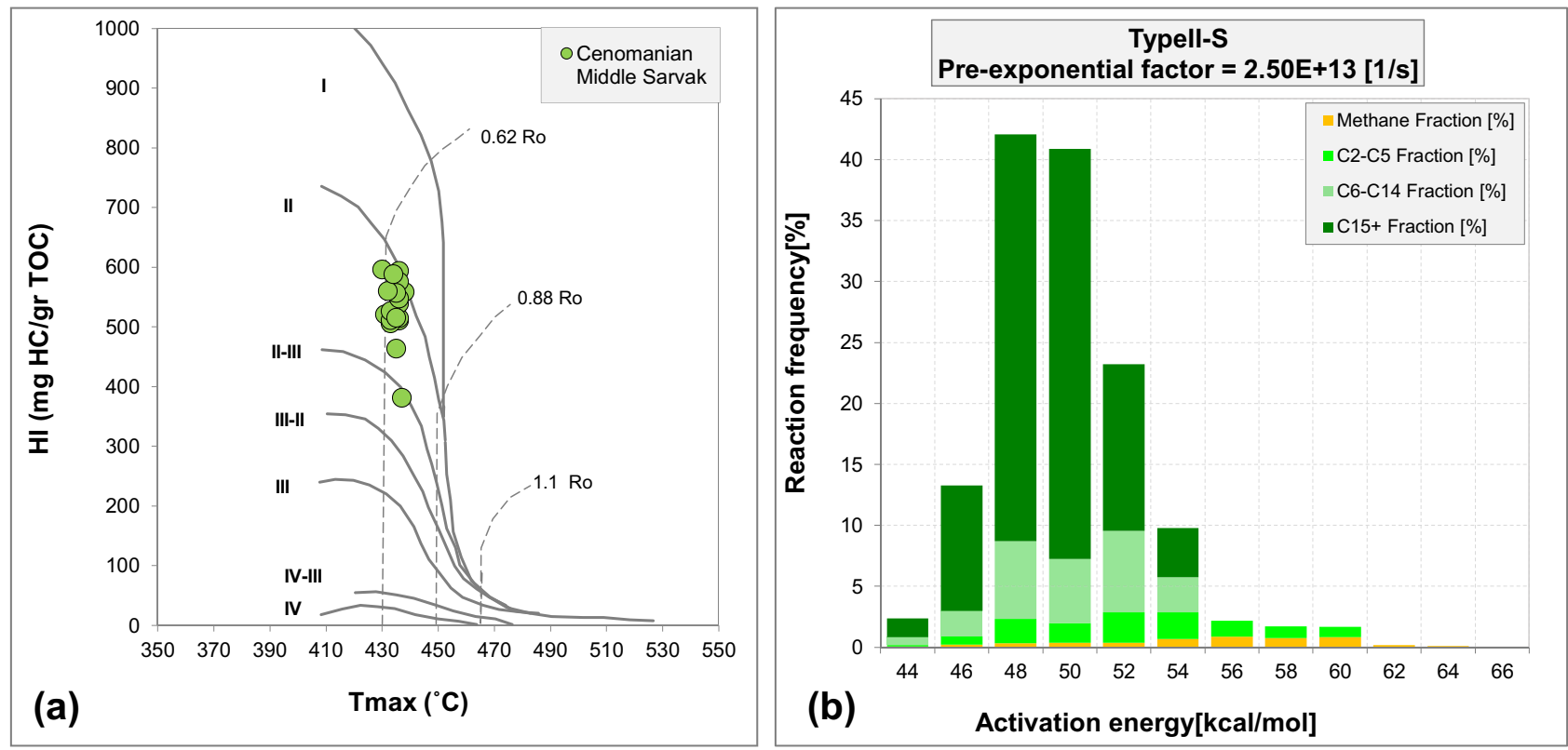

Fig. 3 Diagrams of HI versus Tmax for defining the type of organic matter within the Middle Sarvak source rock (a), and compositional kinetic data typical for type II-S organic matter used from modeling hydrocarbon generation in this study (b)

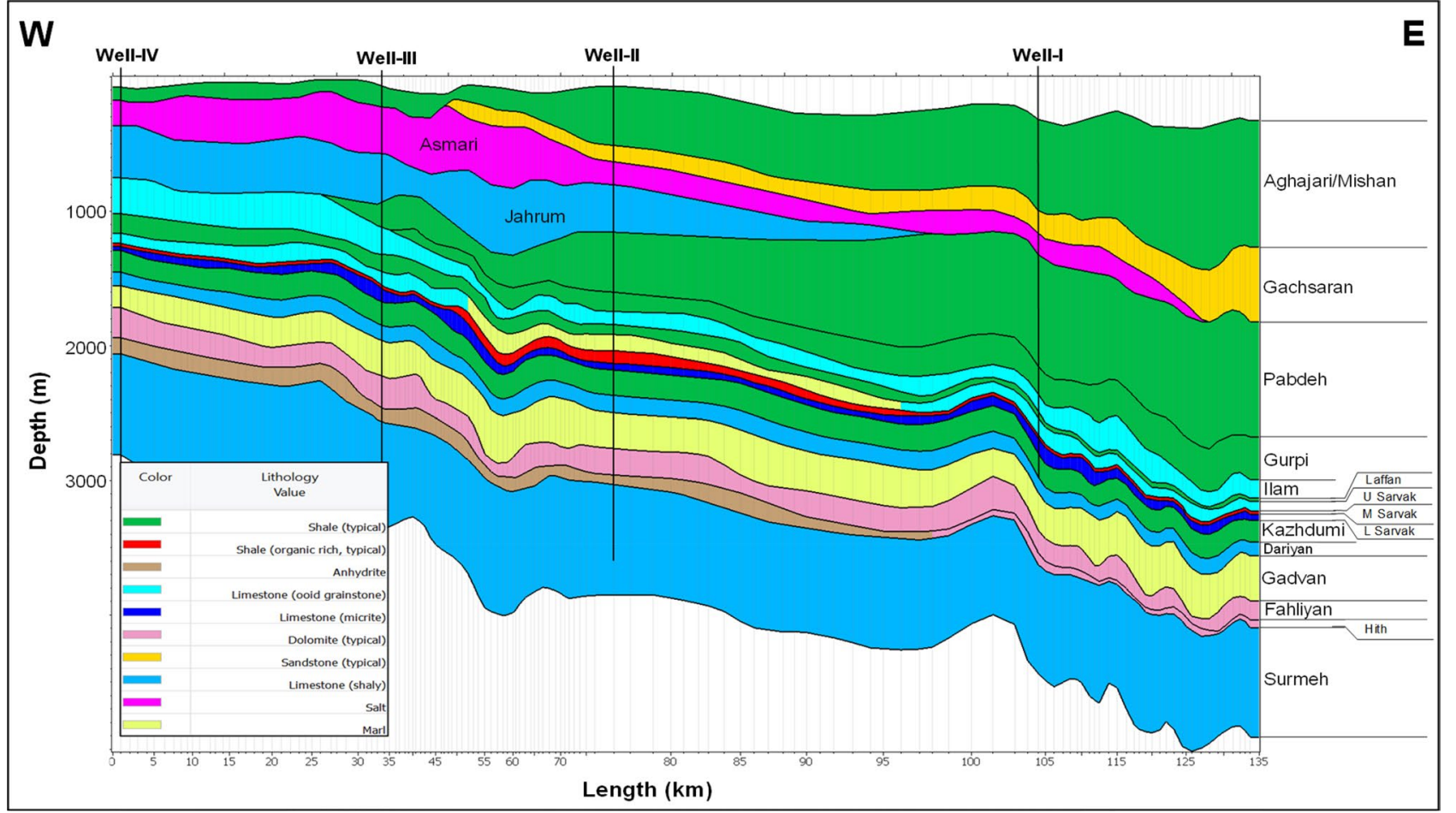

Fig. 4 Snapshot of the present-day stratigraphy of the 2D conceptual model constructed in the eastern Persian Gulf basin (see Fig. 2 for section location). Data from four wells located on the cross section were used for calibration

When such early hydrocarbon generation phases occur within a basin, two critical factors should be carefully examined: (a) timing of trap formation, and (b) seal efficiency.
If these requirements are not satisfied in the studied basin, small chances of preservation will exist for the generated hydrocarbons. In our study area, structural deformation 


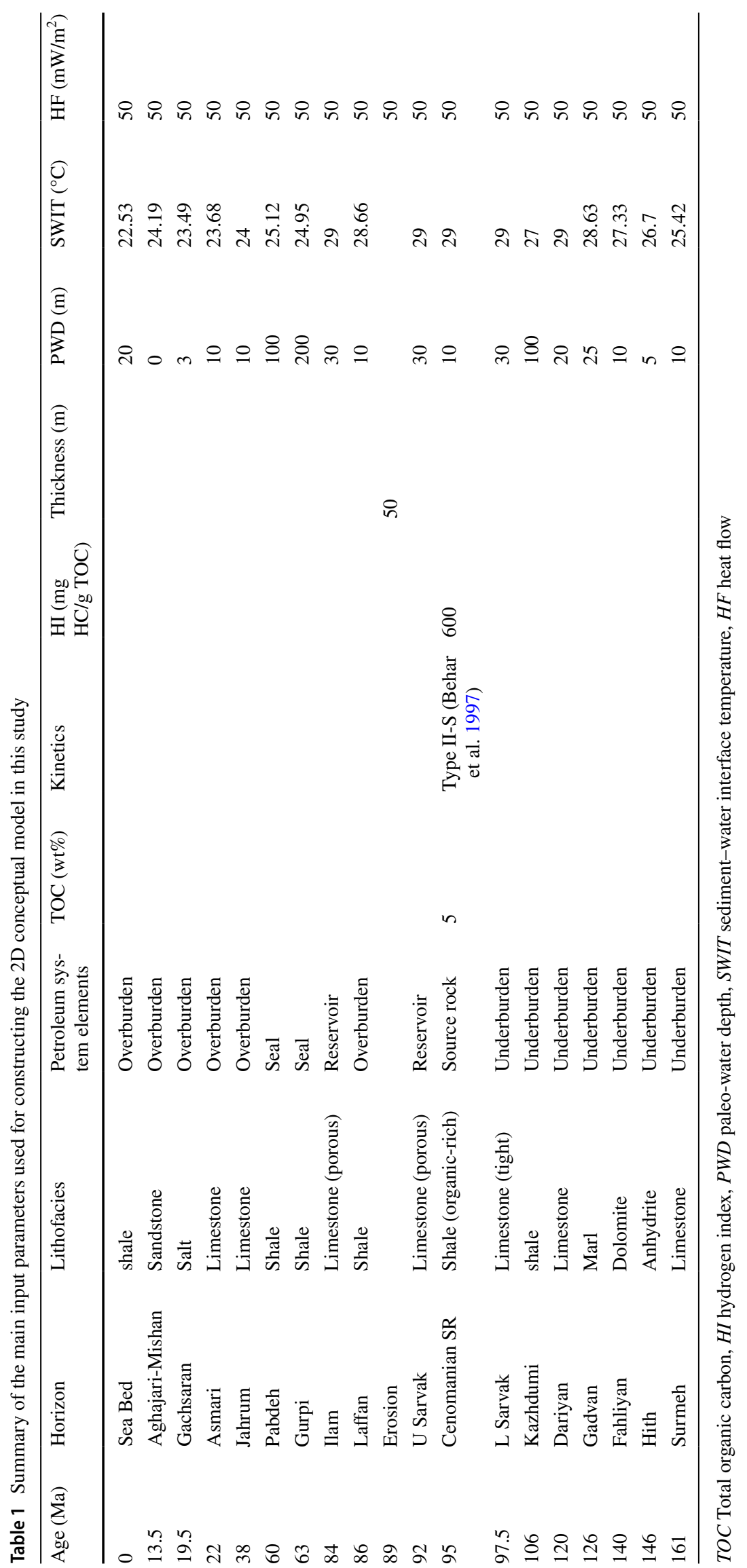




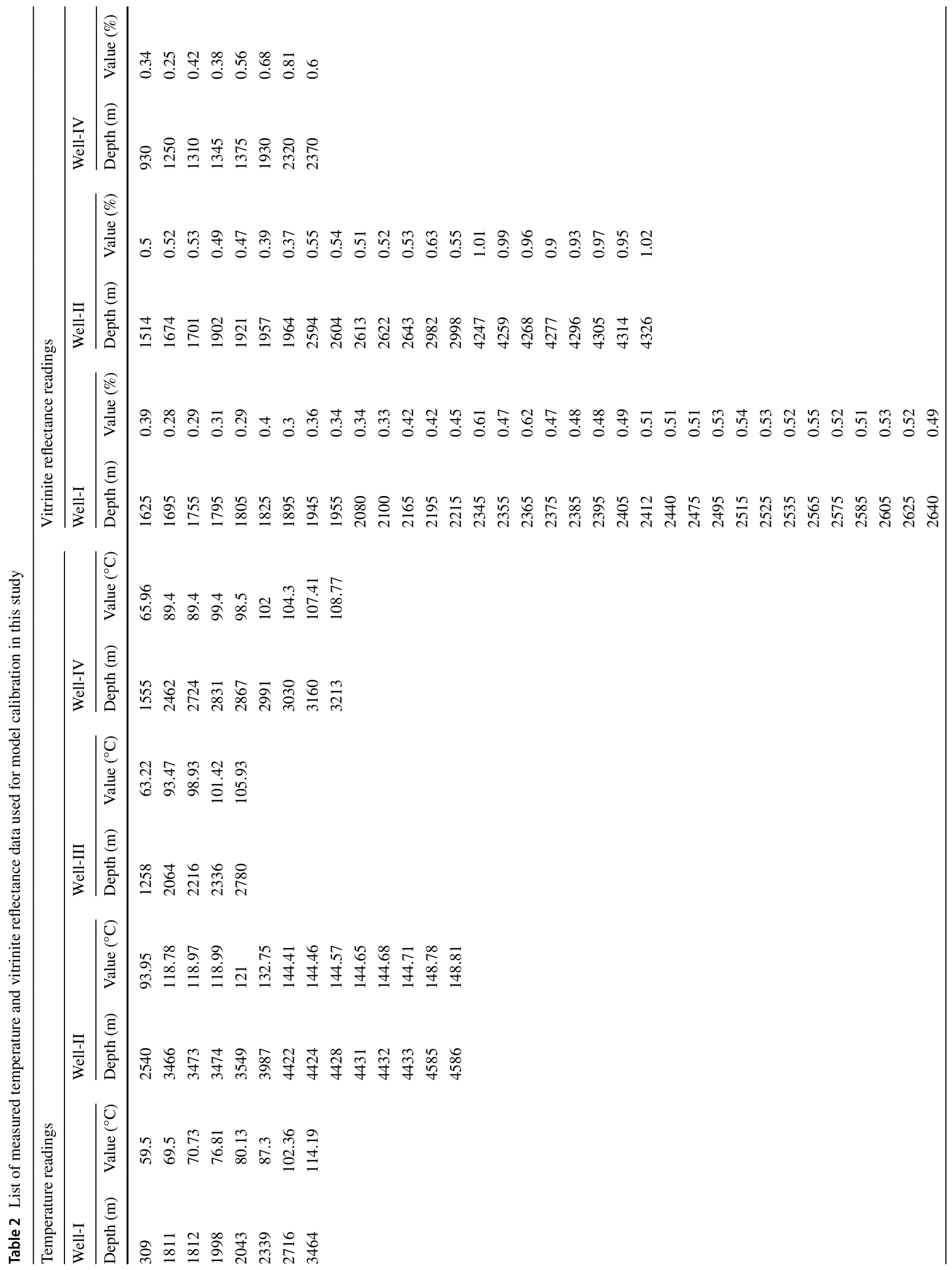




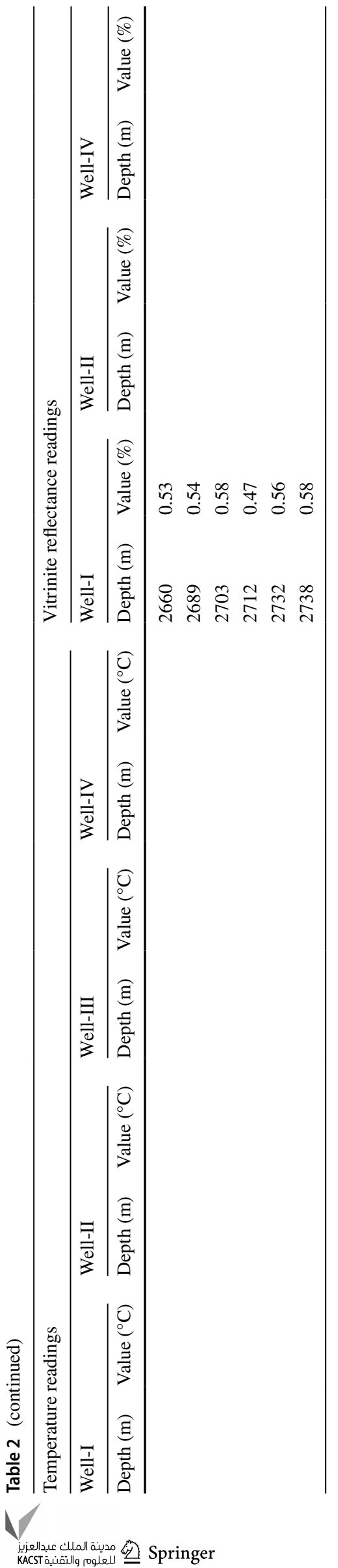

associated with salt tectonics was active since Late Paleozoic (Motamedi and Gharabeigli, 2019) or Jurassic times (Edgell, 1996). These episodic salt movements resulted in the erosion and karstification of the upper parts of the Sarvak Formation in the crest of many structures in the Persian Gulf basin (Ghazban, 2007; Hajikazemi et al. 2010; Videtich et al. 1988). This observation suggests that traps in our study area were available prior to the beginning of hydrocarbon generation from the source rock. Similarly, interbedded shales of the Laffan Formation or the thick shales of the Gurpi and Pabdeh formations could act as efficient seal rocks for the Upper Sarvak and Ilam reservoirs in the study area.

Another phase of pronounced burial and enhanced hydrocarbon generation is evidenced during the deposition of the Middle Miocene Aghajari/Mishan sequences (i.e., from c.a. $13 \mathrm{Ma}$ ). Again, the relatively higher thickness of these sediments on the eastern parts could result in relatively higher thermal stress for the source rock compared to the western parts (Fig. 7). These observations suggest that the geodynamic evolution of the study area is largely responsible for the observed variations in the hydrocarbon generation behavior of the Middle Sarvak source rock.

Westward, the level of thermal maturity decreases for the Middle Sarvak source rock due to shallower burial until the source rock lies in the early stages of oil window near WellII (Figs. 6, 7). This regional trend of maturity evolution has direct implications for defining the geographic extension of the pod of active source rock in the Cretaceous petroleum system. In addition, it suggests that lateral migration would be the prevalent form of fluid migration from the east toward the west of the study area (i.e., from kitchen areas in the east toward accumulations sites on the west) (Fig. 8).

\section{Migration and accumulation}

Fluid flow migration was performed on the 2D model using the hybrid method that considered Darcy-flow and flowpath analyses to predict both the magnitude and direction of migration vectors (Hantschel and Kauerauf, 2009). Based on the migration modeling results (Fig. 8), generated hydrocarbons experience upward vertical migration into the porous carbonates of the Upper Sarvak Formation. These carbonates are composed of highly porous facies, especially in the eastern parts of the studied section. Therefore, they can act as potential avenues for upward lateral migration of hydrocarbons (Fig. 8).

The impermeable Laffan Formation provides a relatively good top-seal for these carrier rocks. Therefore, any geometric closure (structural and/or stratigraphic) within the Upper Sarvak Formation would serve as a potential accumulation site for migrating hydrocarbons. Accordingly, three prospects were predicted by our model, which correlated well with the present-day distribution of producing fields in the 


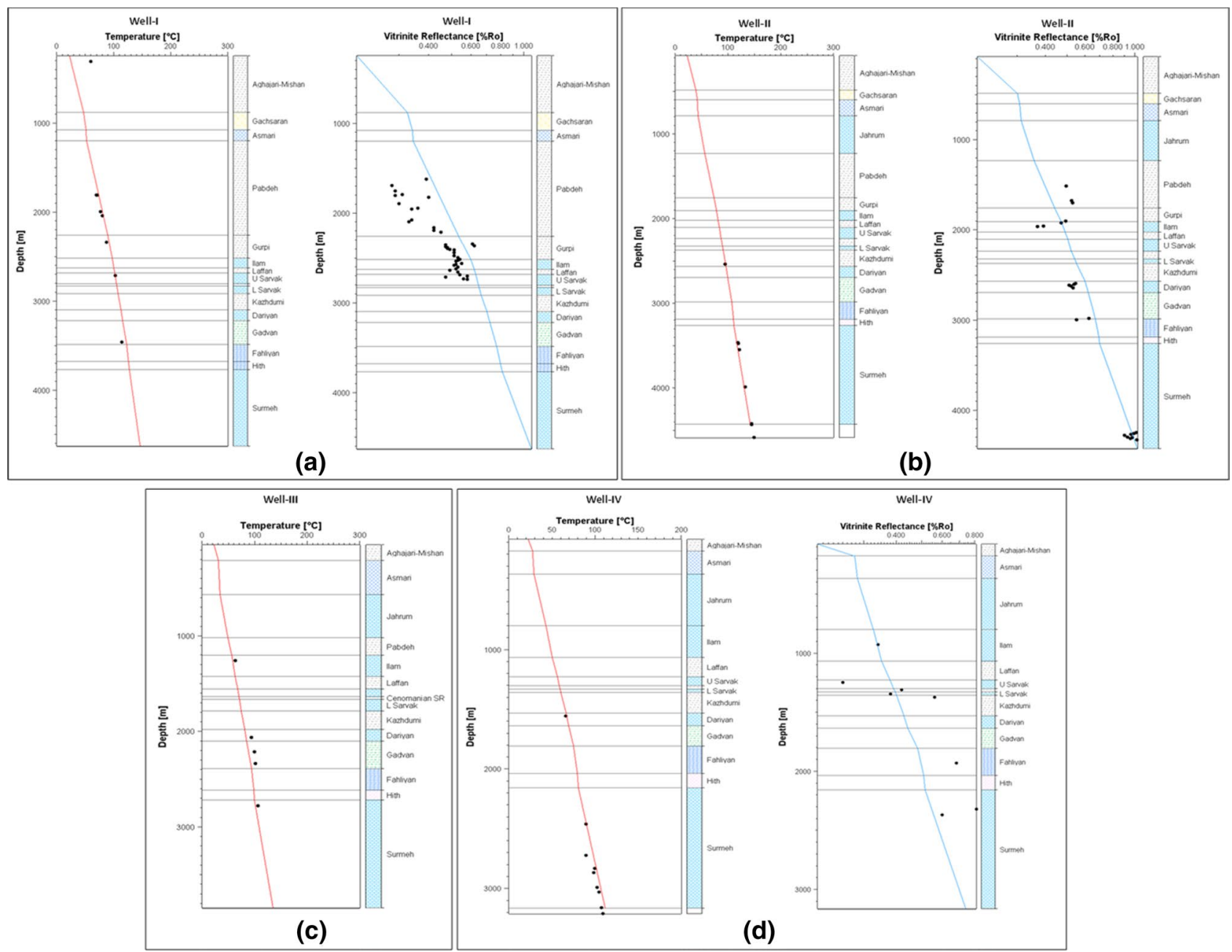

Fig. 5 Calibration profiles for modeled section at Well-I (a), Well-II (b), Well-III (c), and Well-IV (d) using the measured temperature and vitrinite reflectance data (see Table 2)

study area (Fig. 8). The measured ${ }^{\circ}$ API gravity data reported from these oilfields further support the westward migration of hydrocarbons in the study area. The oilfield located in the vicinity of Prospect-I contains an oil with $30^{\circ} \mathrm{API}$ gravity in the Upper Sarvak reservoir, while other oilfields located near Prospect-II and Prospect-III produce oils with $27^{\circ} \mathrm{API}$ and $26^{\circ}$ API gravity, respectively. This observation suggests that Prospect-I is closest to the kitchen area and that hydrocarbons generally migrate westward in the study area.

Our modeling results also provide evidence to support that the existing ${ }^{\circ}$ API gravities are not a result of secondary alteration processes such as biodegradation. For this, we analyzed the trap charge dynamics in the three identified prospects. A synthesis of the Upper Sarvak cell histories (Fig. 9) indicates that the major phase of hydrocarbon emplacement has occurred at c.a. $13 \mathrm{Ma}$ in all three prospects. Interestingly, the temperature of the reservoir cells had already reached pasteurization temperatures around this time (Fig. 9). Head et al. (2003) reported that biological activities tend to be considerably reduced at temperatures above $80^{\circ} \mathrm{C}$. Therefore, the Upper Sarvak reservoir conditions would be favorable for preservation of early charges from degradation by micro-organisms.

However, consistent with the general geology of the study area, modeling results suggest that the risk of finding biodegraded reserves will increase moving upward in the studied section (e.g., within the low-temperature Ilam reservoir). This is consistent with previous modeling studies suggesting moderate levels of biodegradation in the Ilam reservoirs of the eastern Persian Gulf basin (Alipour, 2017; Alipour et al. 2017, 2016a). In addition, the chance for biological alteration of hydrocarbons progressively increases westward within the studied section (i.e., shallower, cooler regions) (Head et al. 2010, 2003). In other words, migrating hydrocarbons within the Upper Sarvak carbonates would progressively rise up to shallower depths 


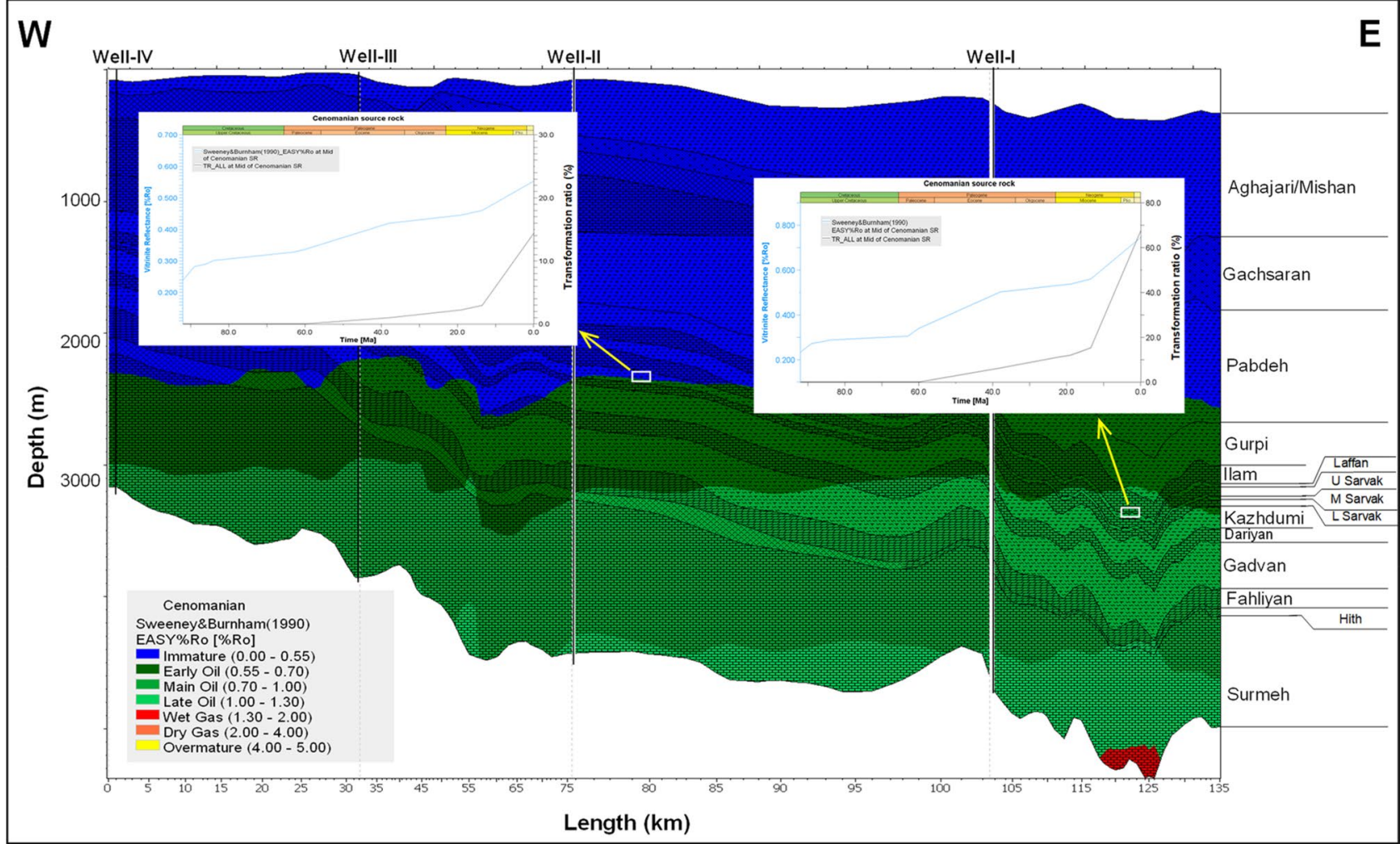

Fig. 6 Evolution of the thermal maturity along the studied section highlighting the transformation ratio (\%) of the Middle Sarvak source rock in the vicinity of Well-I and Well-II

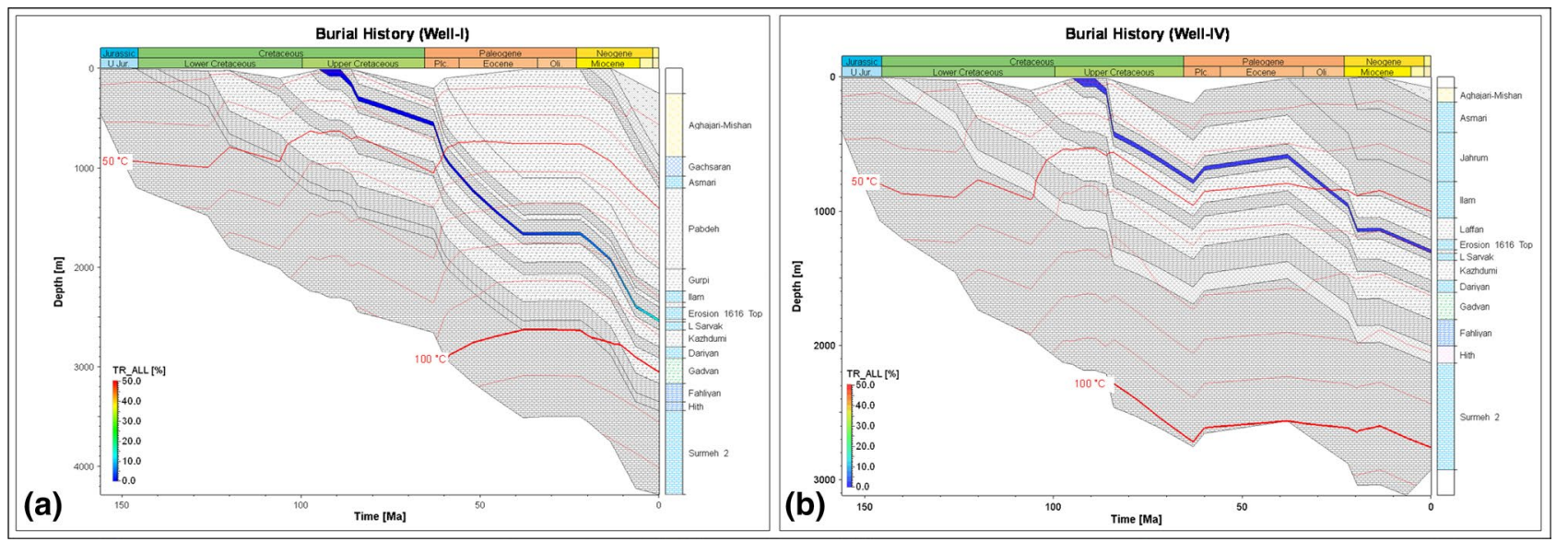

Fig. 7 Comparison of burial history plots from Well-I (a) and Well-IV (b), illustrating the difference in burial depth and maturation level from east to west of the studied section 


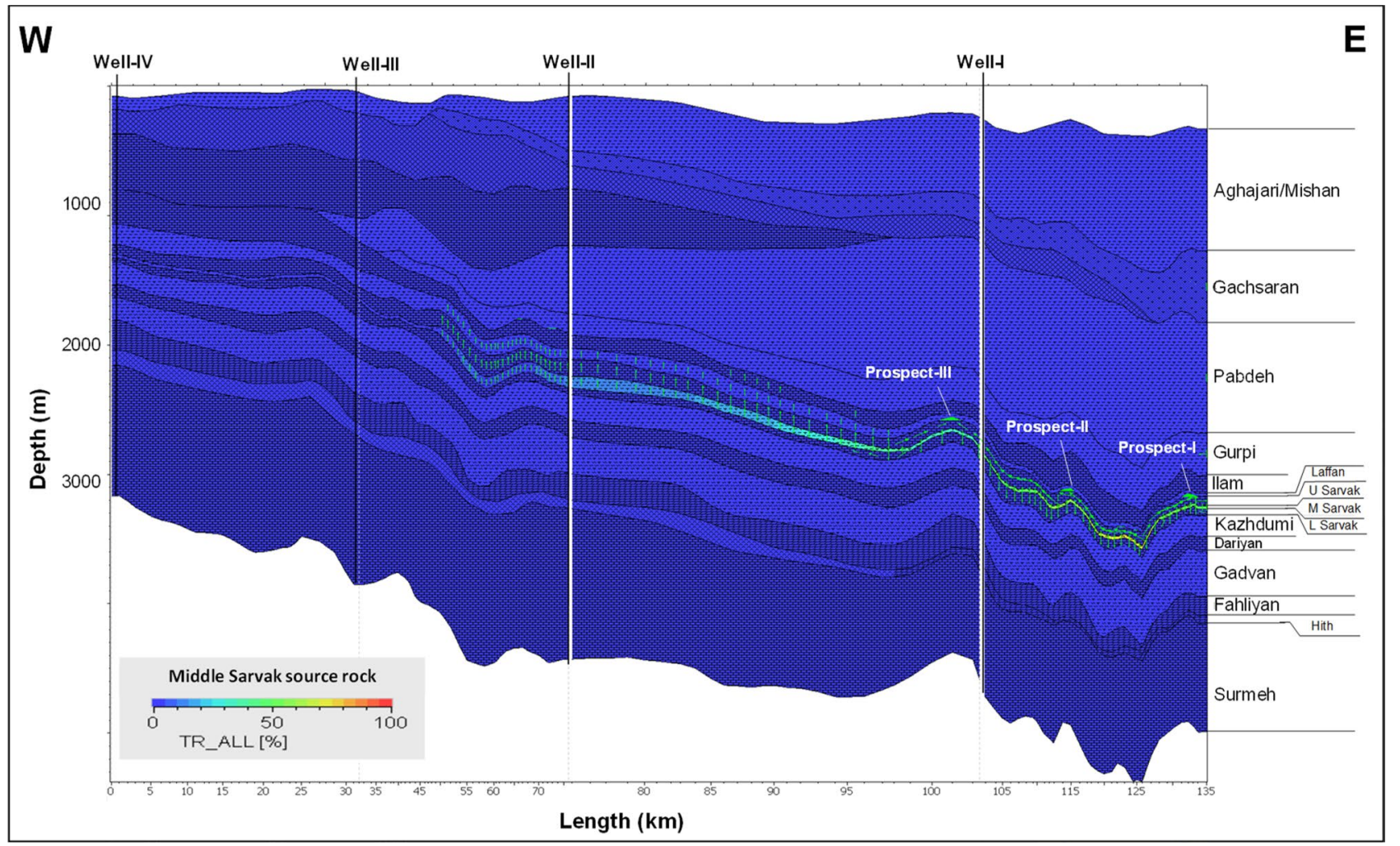

Fig. 8 Snapshot showing the migration pf generated hydrocarbons and the present-day distribution of hydrocarbon accumulations along the studied section

during updip migration. This is consistent with geological observations regarding the occurrence of heavy bitumen in the Upper Sarvak carbonates at several fields lying to the west of the study area. Therefore, due to the influence of extensive biodegradation, the majority of these hydrocarbons will appear in the form of heavy oil (bitumen) impregnations.

Another important implication that can be drawn from migration modeling results is that a new unconventional play can be associated with the Middle Sarvak source rock, especially in the central parts of the basin (Fig. 10). Several factors contribute to the association of promising shale oil resource potential with this source rock in mentioned areas: (a) the lower thermal maturity of the source rock equivalent to the early oil window, (b) the relatively higher thickness of the source rock interval (i.e., lower expulsion efficiency), (c) the lower permeability of the Upper Sarvak carbonates immediately lying above the source rock which prohibits effective drainage of generated products, and (d) the presence of a thick layer of the impermeable Laffan shales which acts as an ultimate sealing rock (Fig. 10). In short, the Middle Sarvak source rock can be a self-contained unconventional resource system in the central parts of the study area. Similar findings are reported from the United Arab Emirates where the organic-rich Shilaif source rock is in the early stages of oil window and overlain by the tight facies of the Tuwayil Formation (Taher, 2010). Nevertheless, we believe that detailed 3D modeling studies are required to fully capture existing facies variations and to better assess the hydrocarbon migration processes in this system. 


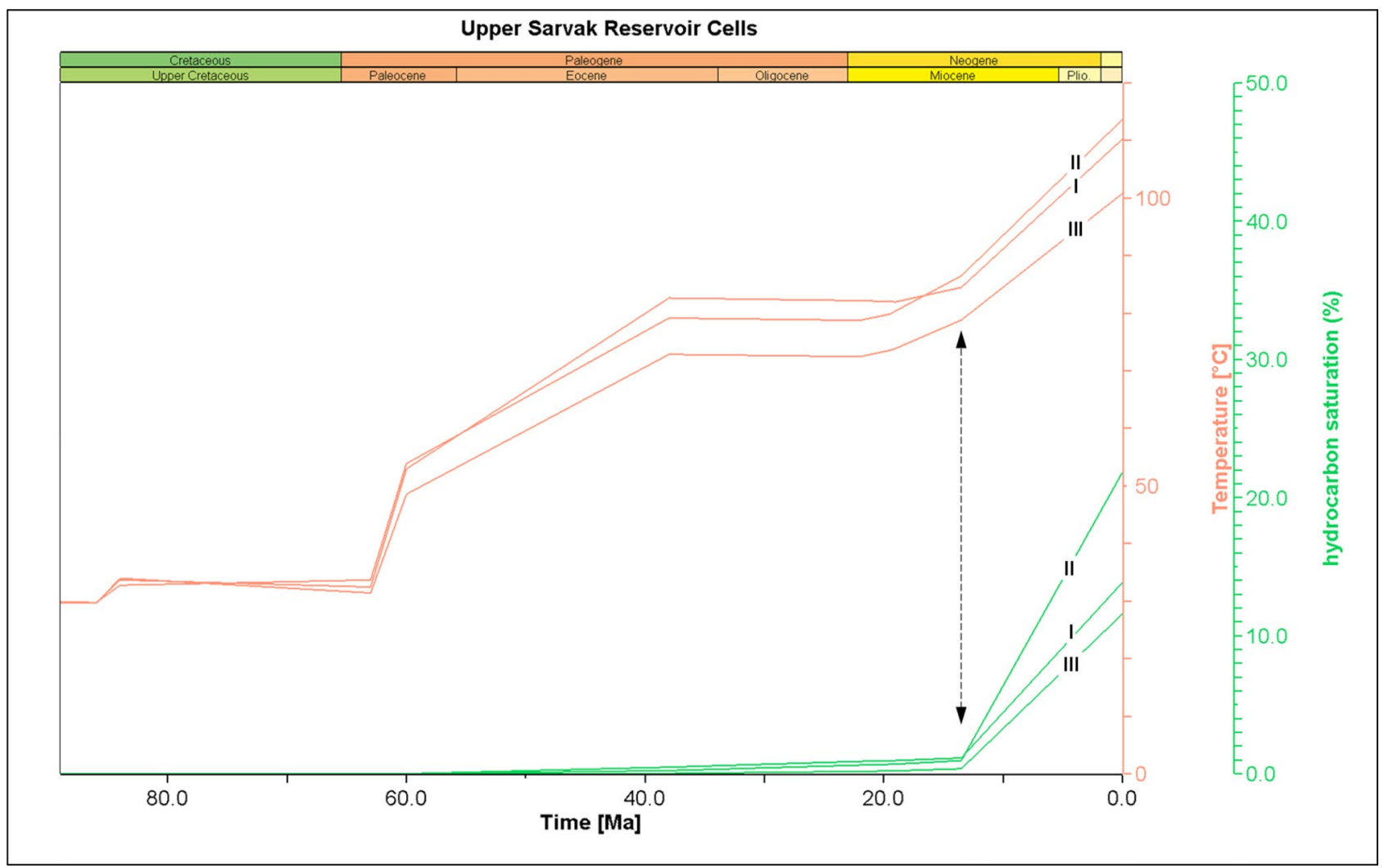

Fig. 9 Graph showing the timing of hydrocarbon emplacement in the Upper Sarvak reservoir cells in three identified prospects and the evolution of associated temperatures

\section{Conclusions}

A calibrated 2D conceptual model was constructed to investigate thermal evolution of the Middle Sarvak source rock (Cenomanian) and analyze the associated petroleum system. The results indicate a strong lateral migration occurring from east to the west of the study area. In addition, the modeling results suggest that the present-day variations in bulk properties of the Upper Sarvak oils are largely controlled by the initial charging mechanisms rather than biodegradation. However, occurrence of biodegradation cannot be neglected in two cases: (a) in the eastern parts where the Laffan shales are thin and hydrocarbons escape vertically into the shallower Ilam reservoir, (b) in the western areas where some hydrocarbons laterally migrate updip inside the carrier rocks. Eventually, our modeling results provide insights about the new unconventional oil paly associated with the Middle Sarvak source rock in the central parts of the eastern Persian Gulf basin. 


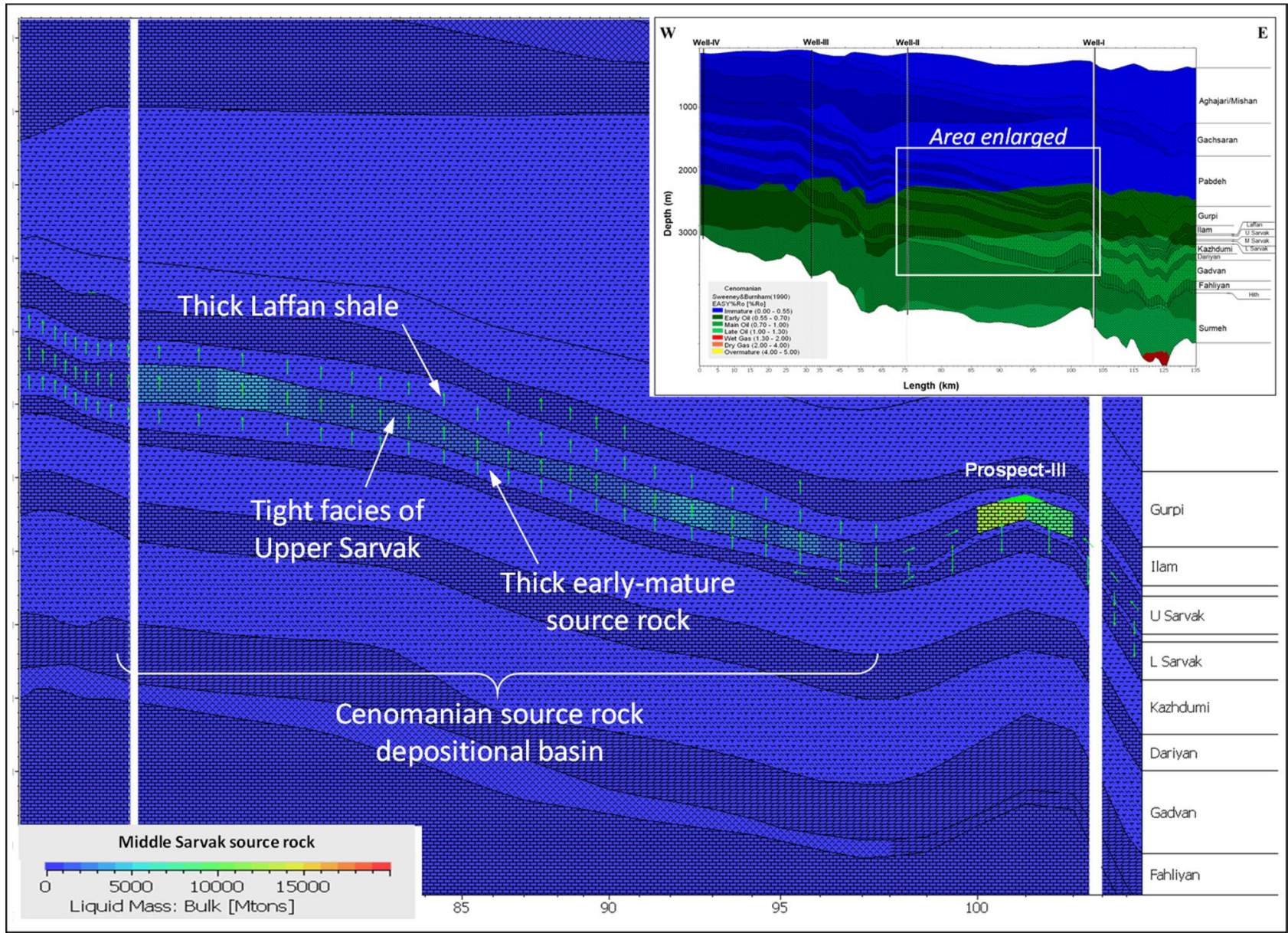

Fig. 10 Modeling results indicating the presence of considerable hydrocarbon masses in the Upper Sarvak carbonates above the thick early mature source rock

Acknowledgements The authors would like to thank department of "petroleum geology and sedimentary basins" of Shahid Chamran University of Ahvaz for supporting this research. Iranian Offshore Oil Company (IOOC) is warmly acknowledged for providing the data and permission to publish. The corresponding author is grateful to the Drilling Research Center (DRC) of Shahid Chamran University of Ahvaz for their support. Comments from anonymous reviewers on earlier versions of this manuscript are acknowledged with thanks.

Funding No funding was provided for doing this research.

\section{Declarations}

Conflict of interest The authors declare no conflict of interest.

Open Access This article is licensed under a Creative Commons Attribution 4.0 International License, which permits use, sharing, adaptation, distribution and reproduction in any medium or format, as long as you give appropriate credit to the original author(s) and the source, provide a link to the Creative Commons licence, and indicate if changes were made. The images or other third party material in this article are included in the article's Creative Commons licence, unless indicated otherwise in a credit line to the material. If material is not included in the article's Creative Commons licence and your intended use is not permitted by statutory regulation or exceeds the permitted use, you will need to obtain permission directly from the copyright holder. To view a copy of this licence, visit http://creativecommons.org/licenses/by/4.0/.

\section{References}

Alipour M, Alizadeh B, Chehrazi A (2017) A thermal maturity analysis of the effective Cretaceous petroleum system in southern Persian Gulf basin. Iran J Oil Gas Sci Technol 6(4):1-17

Alipour M, Alizadeh B, Mirzaei S (2021) Tectono-stratigraphic evolution of the Permo-Triassic series in the Fars Platform of Iran: implications for future exploration of the Paleozoic petroleum system. J Asian Earth Sci 221:104945

Alipour M, Mirzaie S, Shakib S, Hassanpour J, Mohebbi A, Alizadeh B (2014) A new approach to visualize molecular organic geochemical data in basin modeling software. In: Proceedings first EAGE basin and petroleum systems modeling workshop2014

Alipour M, Alizadeh B, Chehrazi A, Mirshahani M, Khani B (2016a) Sequence stratigraphic control on active petroleum system in the eastern Block A, Persian Gulf. In: The 1st international conference on science and basic research: kharazmi higher institute of science and technology, Iran, pp 151-153. 
Alipour M, Alizadeh B, Chehrazi A, Mirzaie S, Shakib S, Khani B, Ramos LS (2016b) Descriptive soruce rock quality mapping based on chemometric classification of bulk geochemical data, Persian Gulf basin. In: Proceedings of the 78th EAGE Conference and Exhibition: Vienna, Austria

Alipour M, Alizadeh B, Ramos LS, Mirzaie S, Chehrazi A (2019) Chemometrics-enhanced classification of source rock samples using their bulk geochemical data, Southern Persian Gulf Basin. Iran J Oil Gas Sci Technol Accepted for publication

Alipour M (2017) Organic geochemistry of source rocks and unconventional resources; habitat and alteration of hydrocarbons in block A of the Persian Gulf [PhD Thesis: Shahid Chamran University of Ahvaz, p 245

Alizadeh B, Alipour M, Chehrazi A, Mirzaie S (2017) Chemometric classification and geochemistry of oils in the Iranian sector of the southern Persian Gulf basin. Org Geochem 111:67-81

Al-Zaabi M, Taher A, Azzam I, Wite J (2010) Geological overview of the middle cretaceous mishrif formation in Abu Dhabi. Soc Petrol Eng SPE 137894:1-18

Ameen FA, Gharib H (2014) Biostratigraphy of the Tethyan cretaceous successions from northwestern Zagros fold-thrust belt, Kurdistan region. NE Iraq Arab J Geosci 7(7):2689-2710

Azzam IN, Taher AK (1993) Sequence stratigraphy and source rock potential of Middle Cretaceous (upper Wasia Group) in west Abu Dhabi. Soc Petrol Eng SPE-25577, pp 305-317.

Baur F, Scheirer AH, Peters K (2017) Past, present and the future of basin and petroleum system modeling. Am Assoc Petrol Geol Bull 102(4):549-561

Behar F, Vandenbroucke M, Tang Y, Marquis F, Espitalie J (1997) Thermal cracking of kerogen in open and closed systems: determination of kinetic parameters and stoichiometric coefficients for oil and gas generation. Org Geochem 26(5):321-339

Edgell H (1996) Salt tectonism in the Persian Gulf basin. Geol Soc Lond Spec Publ 100(1):129-151

Ghajar A, Kamali MR, Mortazavi SAR (2011) Investigating cap rock efficiency of Laffan Shale Formation in Sirri Oilfields, offshore Iran. Adv Petrol Explor Develop 1(1):14-21

Ghazban F (2007) Petroleum geology of the Persian Gulf, Tehran, Iran. Tehran University, Tehran, p 734

Hajikazemi E, Al-Aasm I, Coniglio M (2010) Subaerial exposure and meteoric diagenesis of the Cenomanian-Turonian Upper Sarvak Formation, southwestern Iran. Geol Soc Lond Spec Publ 330(1):253-272

Hantschel T, Kauerauf AI (2009) Fundamentals of basin and petroleum systems modeling. Springer, New York, p 476

Head IM, Jones DM, Larter SR (2003) Biological activity in the deep subsurface and the origin of heavy oil. Nature 426(6964):344-352

Head I, Larter S, Gray N, Sherry A, Adams J, Aitken C, Jones D, Rowan A, Huang H, Röling W (2010) Hydrocarbon degradation in petroleum reservoirs. In: Timmis KN, McGenity TJ, van der Meer JR, Lorenzo VD (eds) Handbook of hydrocarbon and lipid microbiology. Springer, New York, pp 3097-3109

Hosseiny E, Rabbani AR, Moallemi A (2016) Source rock characterization of the Cretaceous Sarvak Formation in the eastern part of the Iranian Sector of Persian Gulf. Org Geochem 99:53-66

Hosseiny E, Rabbani AR, Moallemi SA (2017) Oil families and migration paths by biological markers in the eastern Iranian sector of Persian Gulf. J Petrol Sci Eng 150:54-68

İnan S, Abu-Ali M, Hakami A (2017) A petroleum system and basin modeling study of northwest and east-central Saudi Arabia: effect of burial history and adjacent rock lithology on the gas potential of the Silurian Qusaiba shales. In Abu-Ali M, Moretti I, Nordgard Bolas HM (eds) Petroleum systems analysis-case studies. American Association of Petroleum Geologists Memoir 114, pp 1-35

Lawa F, Koyi H, Ibrahim A (2013) Tectono-stratigraphic evolution of the NW segment OF the Zagros fold-thrust belt, Kurdistan. NE Iraq J Petrol Geol 36(1):75-96
Loutfi G, El Bishlawy S (1986) Habitat of hydrocarbon in Abu Dhabi, UAE. In: Proceedings technical papers and case studies presented at the Symposium on the hydrocarbon potential of intense thrust zones. OAPEC/ADNOC Conference. Abu Dhabi, United Arab Emirates, vol 2, pp 65-124

Magoon LB, Dow WG (1994) The petroleum system. In: Magoon LB, Dow WG (eds) The petroleum system-from source to trap, vol 60. American Association of Petroleum Geologists, pp 3-24

Motamedi H, Gharabeigli G (2019) Structural style in the fars geological province: interaction of diapirism and multidetachment folding, developments in structural geology and tectonics, vol 3. Elsevier, Hoboken, pp 145-160

Motiei H (1993) Stratigraphy of zagros. In: Hushmandzadeh A (ed) Treatise of geology of Iran, vol 1. Tehran, Geological Survey of Iran, p 536

OEOC (2014) PC2000 Marine seismic operation. http://www.oeoc.ir/ marine-operations.html. Accessed on 2014

Omar AA, Lawa FA, Sulaiman S (2015) Tectonostratigraphic and structural imprints from balanced sections across the northwestern Zagros fold-thrust belt, Kurdistan region. NE Iraq Arab J Geosci 8(10):8107-8129

Peters KE, Schenk O, Scheirer AH, Wygrala B, Hantschel T (2017) Basin and petroleum system modeling. In: Hsu CS, Robinson PR (eds) Springer handbook of petroleum technology. Springer, New York, pp 381-417

Rabbani AR, Kotarba MJ, Baniasad AR, Hosseiny E, Wieclaw D (2014) Geochemical characteristics and genetic types of the crude oils from the Iranian sector of the Persian Gulf. Org Geochem 70:29-43

Razin P, Taati F, Van Buchem F (2010) Sequence stratigraphy of Cenomanian-Turonian carbonate platform margins (Sarvak Formation) in the High Zagros, SW Iran: an outcrop reference model for the Arabian Plate. Geol Soc Lond Spec Publ 329(1):187-218

Sharland PR, Archer R, Casey DM, Davies R, Hall SH, Heward AP, Horbury AD, Simmons M (2001) Arabian plate sequence stratigraphy. Manama Bahrain Gulf PetroLink 4:370

Sweeney JJ, Burnham AK (1990) Evaluation of a simple model of vitrinite reflectance based on chemical kinetics. Am Assoc Petrol Geol Bull 74(10): 1559-1570

Taher A (2010) Unconventional oil exploration potential in early mature source rock kitchens. Soc Petrol Eng SPE-137897, pp 1-13

Vahrenkamp V, Franco BJ, Popa D, Barata J, Grelaud C, Razin P, Grosheny D, Bulot L (2015) Development and infill of the Late Albian to Turonian Shilaif intrashelf basin at the Eastern margin of the giant Mesozoic Arabian carbonate platform. In: Basin architecture and time stratigraphy International Petroleum Technology Conference, IPTC-18488-MS: Doha, Qatar

Van Buchem FS, Razin P, Homewood PW, Oterdoom WH, Philip J (2002) Stratigraphic organization of carbonate ramps and organicrich intrashelf basins: Natih Formation (middle Cretaceous) of northern Oman. Am Assoc Petrol Geol Bull 86(1):21-53

Van Buchem F, Simmons M, Droste H, Davies R (2011) Late Aptian to Turonian stratigraphy of the eastern Arabian Plate-depositional sequences and lithostratigraphic nomenclature. Petrol Geosci 17(3):211-222

Videtich PE, McLimans RK, Watson HKS, Nagy RM (1988) Depositional, diagenetic, thermal, and maturation histories of Cretaceous Mishrif Formation, Fateh field. Dubai Am Assoc Petrol Geol Bull 72(10):1143-1159

Wygrala B (1989) Integrated study of an oil field in the southern Po basin, northern Italy. Publikationen vor 2000

Publisher's Note Springer Nature remains neutral with regard to jurisdictional claims in published maps and institutional affiliations. 